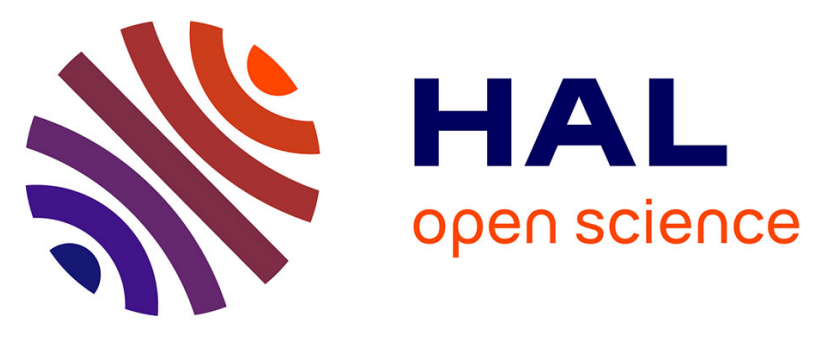

\title{
Microtubule cytoskeleton regulates Connexin 43 localization and cardiac conduction in cardiomyopathy caused by mutation in A-type lamins gene
}

Coline Macquart, Rene Jüttner, Blanca Morales Rodriguez, Caroline Le Dour, Florence Lefebvre, Maria Chatzifrangkeskou, Alain Schmitt, Michael

Gotthardt, Gisèle Bonne, Antoine Muchir

\section{To cite this version:}

Coline Macquart, Rene Jüttner, Blanca Morales Rodriguez, Caroline Le Dour, Florence Lefebvre, et al.. Microtubule cytoskeleton regulates Connexin 43 localization and cardiac conduction in cardiomyopathy caused by mutation in A-type lamins gene. Human Molecular Genetics, 2018, 28 (24), pp.4043-4052. 10.1093/hmg/ddy227 . hal-02505679

\section{HAL Id: hal-02505679 \\ https://hal.sorbonne-universite.fr/hal-02505679}

Submitted on 11 Mar 2020

HAL is a multi-disciplinary open access archive for the deposit and dissemination of scientific research documents, whether they are published or not. The documents may come from teaching and research institutions in France or abroad, or from public or private research centers.
L'archive ouverte pluridisciplinaire HAL, est destinée au dépôt et à la diffusion de documents scientifiques de niveau recherche, publiés ou non, émanant des établissements d'enseignement et de recherche français ou étrangers, des laboratoires publics ou privés. 
Microtubule cytoskeleton regulates connexin 43 localization and cardiac conduction in cardiomyopathy caused by mutation in A-type lamins gene

Coline Macquart ${ }^{1}$, Rene Jüttner ${ }^{2}$, Blanca Morales Rodriguez ${ }^{1}$, Caroline Le Dour ${ }^{3,4}$, Florence Lefebvre ${ }^{5}$, Maria Chatzifrangkeskou ${ }^{1}$, Alain Schmitt ${ }^{6}$, Michael Gotthardt ${ }^{7,8}$, Gisèle Bonne ${ }^{1}$, Antoine Muchir ${ }^{1 *}$

${ }^{1}$ Sorbonne Université, INSERM, Association Institut de Myologie, Centre de Recherche en Myologie, UMRS974, Paris, France

${ }^{2}$ Max-Delbrück-Center for Molecular Medicine, DE-13092 Berlin, Germany

${ }^{3}$ Department of Medicine, College of Physicians and Surgeons, Columbia University, New York, NY

${ }^{4}$ Department of Pathology and Cell Biology, College of Physicians and Surgeons, Columbia University, New York, NY

${ }^{5}$ Signaling and cardiovascular Pathophysiology, UMRS 1180, Université Paris-Sud, INSERM

${ }^{6}$ Institut Cochin, INSERM U1016-CNRS UMR 8104, Université Paris Descartes-Sorbonne Paris Cité, Paris, F-75014, France

${ }^{7}$ DZHK (German Centre for Cardiovascular Research), Berlin, Germany

${ }^{8}$ Neuromuscular and Cardiovascular Cell Biology, Max Delbrück Center for Molecular Medicine,

Robert-Rössle-Str. 10, 13092 Berlin, Germany

*Correspondence:

Antoine Muchir

Center of Research in Myology

UPMC-Inserm UMR974

Institut de Myologie

G.H. Pitie Salpetriere

F-75651 Paris Cedex 13, France

Email: a.muchir@institut-myologie.org 


\begin{abstract}
Mutations in the lamin $\mathrm{A} / \mathrm{C}$ gene $(L M N A)$ cause an autosomal dominant inherited form of dilated cardiomyopathy associated with cardiac conduction disease (hereafter referred to as LMNA cardiomyopathy). Compared with other forms of dilated cardiomyopathy, mutations in LMNA are responsible for a more aggressive clinical course due to a high rate of malignant ventricular arrhythmias. Gap junctions are intercellular channels that allow direct communication between neighboring cells, which are involved in electrical impulse propagation and coordinated contraction of the heart. For gap junctions to properly control electrical synchronization in the heart, connexin-based hemichannels must be correctly targeted to intercalated discs, $\mathrm{Cx} 43$ being the major connexin in the working myocytes. We here showed an altered distribution of $\mathrm{Cx} 43$ in a mouse model of $L M N A$ cardiomyopathy. However, little is known on the molecular mechanisms of $\mathrm{Cx} 43$ remodeling in pathological context. We now show that microtubule cytoskeleton alteration and decreased acetylation of $\alpha$-tubulin lead to remodeling of $\mathrm{Cx} 43$ in $L M N A$ cardiomyopathy, which alters the correct communication between cardiomyocytes, ultimately leading to electrical conduction disturbances. Preventing or reversing this process could offer a strategy to repair damaged heart. Stabilization of microtubule cytoskeleton using Paclitaxel improved intraventricular conduction defects. These results indicate that microtubule cytoskeleton contributes to the pathogenesis of $L M N A$ cardiomyopathy and that drugs stabilizing the microtubule may be beneficial for patients.
\end{abstract}

Keywords : cardiac conduction system, cardiomyopathy, connexin, lamins, microtubules 


\section{INTRODUCTION}

Cardiac conduction disease is a severe and a potentially life threatening disorder (1), which can be caused by genetic mutations (2-10). In 1999, mutations in the lamin $\mathrm{A} / \mathrm{C}$ gene (LMNA) were reported to cause an autosomal dominant inherited form of dilated cardiomyopathy associated with cardiac conduction disease (hereafter referred to as LMNA cardiomyopathy) $(11,12)$. Compared with other forms of dilated cardiomyopathy, mutations in $L M N A$ are responsible for a more aggressive clinical course due to a high rate of conduction defects and malignant ventricular arrhythmias (13-15), often leading to premature death or cardiac transplant (14-17). Conduction defects and ventricular arrhythmias are often the first manifestation of the disease $(13,14)$. A recent study pinpointed that only one half of the patients carrying $L M N A$ mutations had a left ventricular fractional shortening $<50 \%$, suggesting that $L M N A$ cardiomyopathy often manifests as a primary arrhythmia independent of muscle disease (15). Among patients who died suddenly, $>40 \%$ had a pacemaker implanted, suggestive of malignant ventricular arrhythmia as a major cause of fatality. Given these findings, cardiologists recommend now that, if a known $L M N A$ carrier requires pacemaker implantation owing to electrical conduction disturbances, an intracardiac cardioverter defibrillator should be placed even if the degree of systolic dysfunction does not meet the generally accepted criteria for primary prophylaxis (18). Although early initiation of treatments may delay progression and prolong the pre-transplantation phase of the disease, more-definitive therapies await better mechanistic understandings of the molecular basis for these electrical conduction disturbances.

$L M N A$ encodes the A-type nuclear lamins, which arise from alternative RNA splicing $(19,20)$ and are the main constituents of nuclear lamina. Despite our gaps in understanding many of their fundamental functions, much of the current research on the A-type lamins is focused on how mutations leading to alterations in these proteins cause dilated cardiomyopathy (21-24), but nothing is known on the mechanisms leading to electrical conduction disturbances. Inter-cellular communication is essential for proper cardiac function. Mechanical and electrical activities must synchronize so that the work of individual cardiomyocytes transforms into the pumping function of the heart (25). Electrical current propagation throughout the heart is mediated through precisely regulated ion movements coordinated by various gap junction proteins. Gap junctions are intercellular channels that 
allow direct communication between neighboring cells and are therefore involved in electrical impulse propagation and coordinated contraction of the heart. The proteins that constitute these channels are the connexins (26). The expression of these connexins $(\mathrm{Cx})$ is restricted to specific cardiac compartments $(27,28), \mathrm{Cx} 43$ being the major connexin in the working myocytes. Altered distribution of connexins contributes to disturbed coordinated cardiac contractile activation and subsequent malignant arrhythmias (29-30). However, little is known on the molecular mechanisms of remodeling of $\mathrm{Cx} 43$ in pathological context. Preventing or reversing this process could offer a strategy to repair damaged heart. A clear understanding of $\mathrm{Cx} 43$ regulation is crucial, especially when disturbances in conduction from malfunctioning gap junction lead to cardiac arrhythmias. We now show that microtubule cytoskeleton alteration leads to remodeling of $\mathrm{Cx} 43$ in $L M N A$ cardiomyopathy, which alters the correct communication between cardiomyocytes, ultimately leading to electrical conduction disturbances. This study opens perspectives for treating these cardiac defects.

\section{RESULTS}

\section{Cardiac remodeling of $\mathrm{Cx} 43$ in $L M N A$ cardiomyopathy alters cell-cell communication}

We set out to unravel the molecular and cellular causes of cardiac electrical conduction disturbances in $L_{m n a}{ }^{\mathrm{H} 222 \mathrm{P} / \mathrm{H} 222 \mathrm{P}}$ mice, a model for dilated cardiomyopathy caused by mutations in $\operatorname{LMNA}$ (31). The male $L m n a^{\mathrm{H} 222 \mathrm{P} / \mathrm{H} 222 \mathrm{P}}$ mice develop progressive electrical conduction defects (Table 1), starting at 4 months of age. Lmna p.H222P corresponds to a human disease-causing mutation associated with dilated cardiomyopathy and arrhythmias (32). Given that development of cardiac conduction abnormalities has been correlated with remodeling of gap junctions and reduced expression of $\mathrm{Cx} 43$ (33), we here examined both $\mathrm{Cx} 43$ expression and localization in the heart of $L m n a^{\mathrm{H} 222 \mathrm{P} / \mathrm{H} 222 \mathrm{P}}$ mice. According to our previous study (34), we observed a decreased Cx43 expression in heart from 5months old Lmna ${ }^{\mathrm{H} 222 \mathrm{P} / \mathrm{H} 222 \mathrm{P}}$ mice compared to age-matched wild type mice (Fig. S1A, S1B). This is followed by a partial loss of gap junctions in hearts from $L m n a^{\mathrm{H} 222 \mathrm{P} / \mathrm{H} 222 \mathrm{P}}$ mice (Figure 1A), as shown by transmission electron microscopy of ultrathin cardiac sections. The intercalated discs in hearts from 
Lmna ${ }^{\mathrm{H} 222 \mathrm{P} / \mathrm{H} 222 \mathrm{P}}$ mice are disorganized and hyper convoluted compared to wild type mice (Figure 1A). At an earlier stage (3 months) of the disease, when no electrical conduction defects were detected by electrocardiography (Table 1), Cx43 undergoes extensive remodeling in Lmna ${ }^{\mathrm{H} 222 \mathrm{P} / \mathrm{H} 222 \mathrm{P}}$ mice. This remodeling is evidenced by $\mathrm{Cx} 43$ staining at lateral plasma membranes ("lateralization") of $30 \%$ of cardiac cells in the whole heart (Figure 1B), as well as in all isolated cardiomyocytes (Figure 1C) from Lmna ${ }^{\mathrm{H} 222 \mathrm{P} / \mathrm{H} 222 \mathrm{P}}$ mice compared to wild type mice.

Cx43 channels are the main conductors of the intercellular current in ventricular cardiomyocytes (30). We hypothesized that remodeling of $\mathrm{Cx} 43$ could be functionally involved in regulating gap junction communication. We assessed the cell-to-cell communication by implementing a dye-coupling experiment (35). We injected carbofluorescein dye into individual cardiomyocytes $e x-$ vivo and monitored the propagation of the dye (Figure 2A) into adjacent cardiomyocytes. We showed that, while the dye was spread longitudinally to the adjacent cardiomyocytes when injected in cardiomyocyte from $\mathrm{Lmna}^{+/+}$mice, it abnormally diffused through the lateral edge of the cells in almost $25 \%$ of injected cardiomyocytes from $L m n a^{\mathrm{H} 222 \mathrm{P} / \mathrm{H} 222 \mathrm{P}}$ mice. (Figure $2 \mathrm{~B}, 2 \mathrm{C}$ ). Taken together, these data imply that lateralization of $\mathrm{Cx} 43$ leads to impaired communication in LMNA cardiomyopathy.

\section{Microtubule cytoskeleton instability causes remodeling of $\mathrm{Cx} 43$}

Trafficking of $\mathrm{Cx} 43$ is regulated in part by the microtubule network (36-37). Given that microtubules are important for $\mathrm{Cx} 43$ localization, we first assessed the organization of microtubule network in Lmna $^{\mathrm{H} 222 \mathrm{P} / \mathrm{H} 222 \mathrm{P}}$ mice. When we examined the organization of $\alpha$-tubulin network by immunolabeling in isolated cardiomyocytes from $L m n a^{\mathrm{H} 222 \mathrm{P} / \mathrm{H} 222 \mathrm{P}}$ mice, we observed a partial alteration of the organization in orthogonal grid compared to wild type mice (Figure 3A). Conversely, the organization of $\alpha$-actinin and desmin, other cytoskeleton components, were not affected in isolated cardiomyocytes from $L m n a^{\mathrm{H} 222 \mathrm{P} / \mathrm{H} 222 \mathrm{P}}$ mice (Fig. S2). Acetylation of microtubules is a post-translational modification associated with microtubule stability. There was alteration of the acetylated $\alpha$-tubulin network (Figure 3B), associated with a decreased expression of acetylated $\alpha$-tubulin (Figure 3C) in isolated 
cardiomyocytes from Lmna ${ }^{\mathrm{H} 222 \mathrm{P} / \mathrm{H} 222 \mathrm{P}}$ mice compared to wild type cells. We next tested the hypothesis that perturbing microtubule stabilization could alter $\mathrm{Cx} 43$ localization. We showed that depolymerization of the microtubule network using nocodazole leads to a remodelling of $\mathrm{Cx} 43$ ("lateralization") in all isolated cardiomyocytes from wild type mice compared to untreated cardiomyocytes (Figure 4). Nocodazole did not change lateralization of $\mathrm{Cx} 43$ in cardiomyocytes from Lmna $^{\mathrm{H} 222 \mathrm{P} / \mathrm{H} 222 \mathrm{P}}$ mice (Figure 4). In contrast, when we stabilized microtubules using taxol, $\mathrm{Cx} 43$ was correctly localized at the intercalated discs of all cardiomyocytes from $L m n a^{\mathrm{H} 222 \mathrm{P} / \mathrm{H} 222 \mathrm{P}}$ mice but not from wild type mice (Figure 4). All together, these results demonstrated an important role of microtubules in the trafficking of $\mathrm{Cx} 43$ in $L M N A$ cardiomyopathy. Furthermore, we demonstrated that stabilizing microtubules using taxol could rescue $\mathrm{Cx} 43$ remodeling.

Paclitaxel could restore $\mathrm{Cx} 43$ localization in vivo and improve conduction defects in LMNA cardiomyopathy

We next tested the hypothesis that a restoration of $\mathrm{Cx} 43$ at the cell-to-cell junction could improve electrical alteration in $L m n a^{\mathrm{H} 222 \mathrm{P} / \mathrm{H} 222 \mathrm{P}}$ mice. We treated 4 month-old $L m n a^{\mathrm{H} 222 \mathrm{P} / \mathrm{H} 222 \mathrm{P}}$ mice with Paclitaxel (i.e. taxol). Following 1 month of treatment, the mice were analyzed by electrocardiography and then sacrificed for biochemical and histological studies (Figure 5A). Paclitaxel increased the acetylated form of $\alpha$-tubulin in $L m n a^{\mathrm{H} 222 \mathrm{P} / \mathrm{H} 222 \mathrm{P}}$ treated mice compared to DMSO-treated mice, as shown by immunoblotting of proteins in cardiac tissue homogenates (Figure 5B). This suggests an in vivo stabilization of microtubule network caused by treatment with Paclitaxel. Immunofluorescence pictures indicated that there was a correct localization of $\mathrm{Cx} 43$ at the intercalated discs in hearts of Lmna $^{\mathrm{H} 222 \mathrm{P} / \mathrm{H} 222 \mathrm{P}}$ mice following Paclitaxel treatment (Figure 5C). Paclitaxel did not alter cellular localization of $\beta$-catenin, another component of intercalated discs (Fig. S3). Compared to DMSOtreated $L m n a^{\mathrm{H} 222 \mathrm{P} / \mathrm{H} 222 \mathrm{P}}$ mice, QRS interval was significantly improved in $L m n a^{\mathrm{H} 222 \mathrm{P} / \mathrm{H} 222 \mathrm{P}}$ mice treated with Paclitaxel (Figure 5D, Table 2). These data demonstrated the involvement of microtubule 
network for $\mathrm{Cx} 43$ trafficking at intercalated discs, which play a role in the development of electrical defects in $L M N A$ cardiomyopathy.

\section{DISCUSSION}

We have shown that microtubule instability leads to an aberrant localization of $\mathrm{Cx} 43$ in cells expressing a cardiomyopathy-causing lamin A variant. In a mouse model of $L M N A$ cardiomyopathy, these microtubules defects induce "lateralization" and un-coupling of $\mathrm{Cx} 43$, leading in part to the development of cardiac dysfunction. These results suggest a novel model in which A-type lamins play a role in Cx43 trafficking and pathophysiology of cardiac conduction defects. In this model, microtubules instability $1 /$ leads to the abnormal trafficking of $\mathrm{Cx} 43$ toward the lateral plasma membrane of cardiomyocytes, 2/ triggers abnormal electrical communication between adjacent cardiomyocytes, and 3/ induces cardiac conduction defects. Stabilization of the microtubule network by Paclitaxel, suppresses these events and improves cardiac conduction. The mechanism by which LMNA mutation leads to microtubule instability remains to be elucidated.

Prolongation of the QRS interval and ventricular arrhythmias are associated with increased mortality in some patient with LMNA cardiomyopathy (15). The QRS interval represents the time taken for the excitatory impulse to propagate throughout the ventricles, which is partly determined by the intercellular connections between myocytes (38). These connections are ensured by gap junctions, which underlie impulse transmission and signaling molecule exchange and are clustered at the intercalated disks linking individual myocytes (39). Genetic knockout of Cx43 in mice is associated with conduction slowing, QRS prolongation and increased susceptibility to ventricular arrhythmias (40-43). In addition, changes in the localization and regulation of $\mathrm{Cx} 43$ and gap junctions has been described in many forms of cardiac diseases and contribute to the arrhythmogenic substrate (44-48). The molecular mechanisms underlying gap junction remodeling remain largely unknown, but their elucidation is paramount to the development of therapies aiming at improving gap junction coupling during disease. Decreased or disorganized gap junction coupling leads to ventricular arrhythmias of sudden cardiac death and contributes to the pathogenesis of LMNA cardiomyopathy. Restoration of 
normal intercellular coupling in the myopathic heart may well serve as a novel target in the treatment of patients with $L M N A$ cardiomyopathy, at risk for lethal ventricular arrhythmias. Microtubules have a well-studied role in the trafficking of $\mathrm{Cx} 43$ to the plasma membrane $(36,49,50)$. Our data indicate that microtubule cytoskeleton may be a focus for therapeutic interventions to preserve cardiac gap junction coupling. Future elucidation of the mechanisms by which microtubule cytoskeleton is altered by Atype lamins mutants could provide a mean to preserve $\mathrm{Cx} 43$ localization to the intercalated discs.

We observed an alteration of the $\alpha$-tubulin network, associated with a decreased expression of acetylated $\alpha$-tubulin in hearts from $L m n a^{\mathrm{H} 222 \mathrm{P} / \mathrm{H} 222 \mathrm{P}}$ mice, which impedes the localization of $\mathrm{Cx} 43$. These data suggest that post-translation modification of $\alpha$-tubulin hampers stabilization of the microtubule cytoskeleton and participates to the pathogenesis of $L M N A$ cardiomyopathy. It has been described that detyrosination of microtubules, another post-translation modification, plays a role in the development of cardiac diseases (51-53). These studies concluded that targeting detyrosination of microtubules may have therapeutic potential in cardiac alteration. To the best of our knowledge, this is the first time that acetylation of $\alpha$-tubulin has been reported in conduction defects and cardiomyopathy. Our work emphasized the key role of post-translation modification of $\alpha$-tubulin in the cardiac function. It would be interesting in the future to further mechanistically assess how acetylation of $\alpha$-tubulin is decreased in LMNA cardiomyopathy. A number of enzymes have been implicated in the regulation of microtubule acetylation including deacetylases (HDAC6, SIRT2) (54,55) and acetyltransferases ( $\alpha$ TAT1, Nat10) (56,57). Recent studies showed that chemical inhibition of Nat10 rescue microtubule reorganization and aberrant nuclear alterations in cells carrying LMNA mutations $(58,59)$. These data suggest a role of A-type lamins in the regulation of acetylation. We plan future studies to assess the role by A-type lamins variants on microtubule acetylation in cardiac cells carrying $L M N A$ mutations.

In conclusion, our experiments demonstrate a novel contributory mechanism for LMNA cardiomyopathy triggered by altered microtubule network and $\mathrm{Cx} 43$ displacement. Moreover, we have shown that rescuing cardiac Cx43 localization using Paclitaxel, is a straightforward therapeutic strategy. Given that Paclitaxel is potentially translatable into therapy, our work supports more studies 
to begin to evaluate the therapeutic benefits to rescue cardiac $\mathrm{Cx} 43$ localization and assess the benefit of such therapy on LMNA cardiomyopathy. The translation from bench-to-bedside could be seen in years to come since Paclitaxel has already been used in therapeutics for several forms of cancer. Moreover, it has been showed that Paclitaxel can be safely administered in patients with underlying cardiac dysfunction (60). Other microtubule-stabilizing agents have been discovered and should also promote further clinical development for cardiac diseases (61). Overall, our work provides adequate grounds for a therapeutic approach based on stabilizing microtubule cytoskeleton for patients with LMNA cardiomyopathy. 


\section{FUNDING}

This work was supported by the Association Française contre les Myopathies, and a grant (PER-SU) by Sorbonne Université to A.M.

\section{AUTHOR CONTRIBUTIONS}

Conceptualization, A.M.; Investigation, C.M., R.J., C.L.D., M.C., F.L., and A.M.; Writing - Original Draft, A.M.; Writing - Review \& Editing, C.M., and A.M.; Funding Acquisition, A.M.; Supervision, A.M.

\section{COMPETING INTERESTS}

All other authors have declared no conflicts of interest. 


\section{REFERENCES}

1. Michaelsson, M., Jonzon, A. and Riesenfeld, T. (1995) Isolated congenital complete atrioventricular block in adult life. Circulation 92, 442e9.

2. Schott, J.J., Benson, D.W., Basson, C.T., Pease, W., Silberbach, G.M., Moak, J.P., Maron, B.J., Seidman, C.E. and Seidman, J.G. (1998) Congenital heart disease caused by mutations in the transcription factor NKX2-5. Science 281, $108-111$.

3. Benson, D.W., Silberbach, G.M., Kavanaugh-McHugh, A., Cottrill, C., Zhang, Y., Riggs, S., Smalls, O., Johnson, M.C., Watson, M.S., Seidman, J.G. et al. (1999) Mutations in the cardiac transcription factor NKX2.5 affect diverse cardiac developmental pathways. J. Clin. Invest. 104, $1567-1573$.

4. Goldmuntz, E., Geiger, E. and Benson, D.W. (2001) NKX2.5 mutations in patients with tetralogy of Fallot. Circulation 104, 2565-2568.

5. McElhinney, D.B., Geiger, E., Blinder, J., Benson, D.W. and Goldmuntz, E. (2003) NKX2.5 mutations in patients with congenital heart disease. J. Am. Coll. Cardiol. 42, $1650-1655$.

6. Arad, M., Benson, D.W., Perez-Atayde, A.R., McKenna, W.J., Sparks, E.A., Kanter, R.J., McGarry, K., Seidman, J.G. and Seidman, C.E. (2002) Constitutively active AMP kinase mutations cause glycogen storage disease mimicking hypertrophic cardiomyopathy. J. Clin. Invest. 109, 357-362.

7. Arad, M., Moskowitz, I.P., Patel, V.V., Ahmad, F., Perez-Atayde, A.R., Sawyer, D.B., Walter, M., Li, G.H., Burgon, P.G., Maguire, C.T. et al. (2003) Transgenic mice overexpressing mutant PRKAG2 define the cause of Wolff-Parkinson-White syndrome in glycogen storage cardiomyopathy. Circulation 107, 2850-2856.

8. Schott, J.J., Alshinawi, C., Kyndt, F., Probst, V., Hoorntje, T.M., Hulsbeek, M., Wilde, A.A., Escande, D., Mannens, M.M. and Le Marec, H. (1999) Cardiac conduction defects associate with mutations in SCN5A. Nat. Genet. 23, $20-21$.

9. Tan, H.L., Bink-Boelkens, M.T., Bezzina, C.R., Viswanathan, P.C., Beaufort-Krol, G.C., van Tintelen, P.J., van den Berg, M.P., Wilde, A.A. and Balser, J.R. (2001) A sodium-channel mutation causes isolated cardiac conduction disease. Nature 409, 1043-1047.

10. Wang, D.W., Viswanathan, P.C., Balser, J.R., George, A.L.Jr and Benson, D.W. (2002) Clinical, genetic, and biophysical characterization of SCN5A mutations associated with atrioventricular conduction block. Circulation 105, 341-346.

11. Bonne, G., Di Barletta, M.R., Varnous, S., Bécane, H.M., Hammouda, E.H., Merlini, L., Muntoni, F., Greenberg, C.R., Gary, F., Urtizberea, J.A. et al. (1999) Mutations in the gene encoding lamin $\mathrm{A} / \mathrm{C}$ cause autosomal dominant Emery- Dreifuss muscular dystrophy. Nat. Genet. 21, 285-288.

12. Fatkin, D., MacRae, C., Sasaki, T., Wolff, M.R., Porcu, M., Frenneaux, M., Atherton, J., Vidaillet, H.J.Jr, Spudich, S., De Girolami, U. et al. (1999) Missense mutations in the rod domain of the lamin $\mathrm{A} / \mathrm{C}$ gene as causes of dilated cardiomyopathy and conduction-system disease. N. Engl. J. Med. 341, 1715-1724.

13. Arbustini, E., Pilotto, A., Repetto, A., Grasso, M., Negri, A., Diegoli, M., Campana, C., Scelsi, L., Baldini, E., Gavazzi, A. et al. (2002) Autosomal dominant dilated cardiomyopathy with atroventricular block: a lamin A/C defect-related disease. J. Am. Coll. Cardiol. 39, 981990.

14. Van Berlo, J.H., de Voogt, W.G., van der Kooi, A.J., van Tintelen, J.P., Bonne, G., Yaou, R.B., Duboc, D., Rossenbacker, T., Heidbüchel, H., de Visser. M. et al. (2005) Meta-analysis of clinical characteristics of 299 carriers of LMNA gene mutations: do lamin A/C mutations portend a high risk of sudden death. J. Mol. Med. 83, 79-83.

15. Kumar, S., Baldinger, S.H., Gandjbakhch, E., Maury, P., Sellal, J.M., Androulakis, A.F., Waintraub, X., Charron, P., Rollin, A., Richard, P. et al. (2016) Long-term arrhythmic and nonarrhythmic outcomes of lamin A/C mutation carriers. J. Am. Coll. Cardiol. 68, 2299-2307.

16. Taylor, M.R., Fain, P.R., Sinagra, G., Robinson, M.L., Robertson, A.D., Carniel, E., Di Lenarda, A., Bohlmeyer, T.J., Ferguson, D.A., Brodsky, G.L. et al. (2003) Familial Dilated Cardiomyopathy Registry Research Group. Natural history of dilated cardiomyopathy due to lamin A/C gene mutations. J. Am. Coll. Cardiol. 41, 771-780. 
17. Pasotti, M., Klersy, C., Pilotto, A., Marziliano, N., Rapezzi, C., Serio, A., Mannarino, S., Gambarin, F., Favalli, V., Grasso, M. et al. (2008) Long-term outcome and risk stratification in dilated cardiolaminopathies. J. Am. Coll. Cardiol. 52, 1250-1260.

18. Meune, C., van Berlo, J.H., Anselme, F., Bonne, G., Pinto, Y.M. and Duboc, D. (2006) Primary prevention of sudden death in patients with lamin A/C gene mutations. N. Engl. J. Med. 354, 209-210.

19. McKeon, F.D., Kirschner, M.W. and Caput, D. (1986) Homologies in both primary and secondary structure between nuclear envelope and intermediate filament proteins. Nature 319, 463-468.

20. Lin, F. and Worman, H.J. (1993) Structural organization of the human gene encoding nuclear lamin A and nuclear lamin C. J. Biol. Chem. 268, 16321-16326.

21. Muchir, A., Pavlidis, P., Decostre, V., Herron, A.J., Arimura, T., Bonne, G. and Worman, H.J. (2007) Activation of MAPK pathways links LMNA mutations to cardiomyopathy in EmeryDreifuss muscular dystrophy. J. Clin. Invest. 117, 1282-1293.

22. Muchir, A., Wu, W., Choi, J.C., Iwata, S., Morrow, J., Homma, S. and Worman, H.J. (2012) Abnormal p38a mitogen-activated protein kinase signaling in dilated cardiomyopathy caused by lamin A/C gene mutation. Hum. Mol. Genet. 21, 4325-4333.

23. Ho, C.Y., Jaalouk, D.E., Vartiainen, M.K. and Lammerding, J. (2013) Lamin A/C and emerin regulate MKL1-SRF activity by modulating actin dynamics. Nature 497, 507-511.

24. Chatzifrangkeskou, M., Le Dour, C., Wu, W., Morrow, J.P., Joseph, L.C., Beuvin, M., Sera, F., Homma, S., Vignier, N., Mougenot, N. et al. (2016) ERK1/2 directly acts on CTGF/CCN2 expression to mediate myocardial fibrosis in cardiomyopathy caused by mutations in the lamin A/C gene. Hum. Mol. Genet. 25, 2220-2233.

25. Noorman, M., van der Heyden, M.A., van Veen, T.A., Cox, M.G., Hauer, R.N., de Bakker, J.M. and van Rijen, H.V. (2009) Cardiac cell-cell junctions in health and disease: Electrical versus mechanical coupling. J. Mol. Cell. Cardiol. 47, 23-31.

26. Sáez, J.C., Berthoud, V.M., Branes, M.C., Martinez, A.D. and Beyer, E.C. (2003) Plasma membrane channels formed by connexins: their regulation and functions. Physiol. Rev. 83, 1359-1400.

27. Kurtenbach, S., Kurtenbach, S. and Zoidl, G. (2014) Gap junction modulation and its implications for heart function. Front. Physiol. 5, 82.

28. Verheule, S. and Kaese, S. (2013) Connexin diversity in the heart: insights from transgenic mouse models. Front. Pharmacol. 4, 81 .

29. Duffy, H.S. (2012) The molecular mechanisms of gap junction remodeling. Heart Rhythm 9 , 1331-1334.

30. Jongsma, H.J. and Wilders, R. (2000) Gap junctions in cardiovascular disease. Circ. Res. 86, 1193-1197.

31. Arimura, T., Helbling-Leclerc, A., Massart, C., Varnous, S., Niel, F., Lacene, E., Fromes, Y., Toussaint, M., Mura, A.M., Keller, D.I. et al. (2005) Mouse model carrying H222P-Lmna mutation develops muscular dystrophy and dilated cardiomyopathy similar to human striated muscle laminopathies. Hum. Mol. Genet. 14, 155-169.

32. Bonne, G., Mercuri, E., Muchir, A., Urtizberea, A., Bécane, H.M., Recan, D., Merlini, L., Wehnert, M., Boor, R., Reuner, U. et al. (2000) Clinical and molecular genetic spectrum of autosomal dominant Emery-Dreifuss muscular dystrophy due to mutations of the lamin $\mathrm{A} / \mathrm{C}$ gene. Ann. Neurol. 48, 170-180.

33. Nademanee, K., Raju, H., de Noronha, S.V., Papadakis, M., Robinson, L., Rothery, S., Makita, N., Kowase, S., Boonmee, N., Vitayakritsirikul, V. et al. (2015) Fibrosis, connexin-43 and conduction abnormalities in the Brugada syndrome. J. Am. Coll. Cardiol. 66, 1976-1986.

34. Le Dour, C., Macquart, C., Sera, F., Homma, S., Bonne, G., Morrow, J.P., Worman, H.J. and Muchir, A. (2016) Decreased WNT/b-catenin signalling contributes to the pathogenesis of dilated cardiomyopathy caused by mutations in the lamin A/C gene. Hum. Mol. Genet. 26, 333-343.

35. Lisewski, U., Shi, Y., Wrackmeyer, U., Fischer, R., Chen, C., Schirdewan, A., Jüttner, R., Rathjen, F., Poller, W., Radke, M.H. et al. (2008) The tight junction protein CAR regulates cardiac conduction and cell-cell communication. J. Exp. Med. 205, 2369-2379. 
36. Shaw, R.M., Fay, A.J., Puthenveedu, M.A., von Zastrow, M., Jan, Y-N. and Jan, L.Y. (2007) Microtubule plus-end-tracking proteins target gap junctions directly from the cell interior to adherens junctions. Cell 2128, 547-560.

37. Smyth, J.W., Hong, T-T., Gao, D., Vogan, J.M., Jensen, B.C., Fong, T.S., Simpson, P.C., Stainier, D.Y.R., Chi, N.C. and Shaw, R.M. (2010) Limited forward trafficking of connexin 43 reduces cell-cell coupling in stressed human and mouse myocardium. J. Clin. Invest. 120, 266-279.

38. Rohr, S. (2004) Role of gap junctions in the propagation of the cardiac action potential. Cardiovasc. Res. 62, 309-322.

39. Severs, N.J., Coppen, S.R., Dupont, E., Yeh, H.I., Ko, Y.S. and Matsushita, T. (2004) Gap junction alterations in human cardiac disease. Cardiovasc. Res. 62, 368-377.

40. Thomas, S.A., Schuessier, R.B., Berul, C.I., Beardslee, M.A., Beyer, E.C., Mendelsohn, M.E. and Saffitz, J.E. (1998) Disparate effects of deficient expression of connexin43 on atrial and ventricular conduction: evidence for chamber-specific molecular determinants of conduction. Circulation 97, 686-691.

41. Gutstein, D.E., Morley, G.E., Vaidya, D., Liu, F., Chen, F.L., Stuhlmann, H. and Fishman, G.I. (2001) Heterogeneous expression of Gap junction channels in the heart leads to conduction defects and ventricular dysfunction. Circulation 104, 1194-1199.

42. Gutstein, D.E., Morley, G.E., Tamaddon, H., Vaidya, D., Schneider, M.D., Chen, J., Chien, K.R., Stuhlmann, H. and Fishman, G.I. (2001) Conduction slowing and sudden arrhythmic death in mice with cardiac-restricted inactivation of connexin43. Circ. Res. 88, 333-339.

43. Danik, S.B., Liu, F., Zhang, J., Suk, H.J., Morley, G.E., Fishman, G.I. and Gutstein, D.E. (2004) Modulation of cardiac gap jcuntion expression and arrhythmic susceptibility. Circ. Res. 95, 1035-1041.

44. Severs, N.J., Dupont, E., Coppen, S.R., Halliday, D., Inett, E., Baylis, D. and Rothery, S. (2004) Remodelling of gap junctions and connexin expression in heart disease. Biochim. Biophys. Acta 1662, 138-148.

45. Severs, N.J., Dupont, E., Thomas, N., Kaba, R., Rothery, S., Jain, R., Sharpey, K. and Fry, C.H. (2006) Alterations in cardiac connexin expression in cardiomyopathies. Adv. Cardiol. 42, 228-242.

46. Kostin, S., Rieger, M., Dammer, S., Hein, S., Richter, M., Klövekorn, W.P., Bauer, E.P. and Schaper, J. (2003) Gap junction remodeling and altered connexin43 expression in the failing human heart. Mol. Cell. Biochem. 242, 135-144.

47. Kostin, S., Dammer, S., Hein, S., Klövekorn, W.P., Bauer, E.P. and Schaper, J. (2004) Connexin 43 expression and distribution in compensated and decompensated cardiac hypertrophy in patients with aortic stenosis. Cardiovasc. Res. 62, 426-436.

48. Sepp, R., Severs, N.J. and Gourdie, R.G. (1996) Altered patterns of cardiac intercellular junction distribution in hypertrophic cardiomyopathy. Heart 76, 412-417.

49. Giepmans, B.N., Verlaan, I., Hengeveld, T., Janssen, H., Calafat, J., Falk, M.M. and Moolenaar, W.H. (2001) Gap junction protein connexin-43 interacts directly with microtubules. Curr. Biol. 11, 1364-1368.

50. Jordan, K., Solan, J.L., Dominguez, M., Sia, M., Hand, A., Lampe, P.D. and Laird, D.W. (1999) Trafficking, assembly, and function of a connexin43-green fluorescent protein chimera in live mammalian cells. Mol. Biol. Cell. 10, 2033-2050.

51. Kerr, J.P., Robinson, P., Shi, G., Bogush, A.I., Kempema, A.M., Hexum, J.K., Becerra, N., Harki, D.A., Martin, S.S., Raiteri, R. et al. (2015) Detyrosinated microtubules modulate mechanotransduction in heart and skeletal muscle. Nat. Commun. 6, 8526.

52. Robinson, P., Caporizzo, M.A., Ahmadzadeh, H., Bogush, A.I., Chen, C.Y., Margulies, K.B., Shenoy, V.B. and Prosser, B.L. (2016) Detyrosinated microtubules buckle and bear load in contracting cardiomyocytes. Science 352, aaf0659.

53. Belmadani, S., Poüs, C., Ventura-Clapier, R., Fischmeister, R. and Méry, P.F. (2002) Posttranslational modifications of cardiac tubulin during chronic heart failure in the rat. Mol. Cell. Biochem. 237, 39-46. 
54. Hubbert, C., Guardiola, A., Shao, R., Kawaguchi, Y., Ito, A., Nixon, A., Yoshida, M., Wang, X.F. and Yao, T.P. (2002) HDAC6 is a microtubule-associated deacetylase. Nature 417, 455458.

55. North, B.J., Marshall, B.L., Borra, M.T., Denu, J.M. and Verdin, E. (2003) The human Sir2 ortholog, SIRT2, is an NAD+-dependent tubulin deacetylase. Mol. Cell. 11, 437-444.

56. Shia, T., Cueva, J.G., Xu, Z., Goodman, M.B. and Nachury, M.V. (2010) The major alphatubulin K40 acetyltransferase alphaTAT1 promotes rapid ciliogenesis and efficient mechanosensation. Proc. Natl. Acad. Sci. USA 107, 21517-21522.

57. Shen, Q., Zheng, X., McNutt, M.A., Guang, L., Wang, J., Gong, Y., Hou, L. and Zhang, B. (2009) NAT10, a nucleolar protein, localizes to the midbody and regulates cytokinesis and acetylation of microtubules. Exp. Cell Res. 315, 1653-1667.

58. Larrieu, D., Britton, S., Demir, M., Rodriguez, R. and Jackson, S.P. (2014) Chemical inhibition of NAT10 corrects defects of laminopathic cells. Science 344, 527-532.

59. Balmus, G., Larrieu, D., Barros, A.C., Collins, C., Abrudan, M., Demir, M., Geisler, N.J., Lelliott, C.J., White, J.K., Karp, N.A. et al. (2018) Targeting of NAT10 enhances healthspan in a mouse model of human accelerated aging syndrome. Nat. Commun. 91, 1700.

60. Gollerkeri, A., Harrold, L., Rose, M., Jain, D. and Burtness, B.A. (2001) Use of paclitaxel in patients with pre-existing cardiomyopathy: a review of our experience. Int. J. Cancer 93, 139141.

61. Zhao, Y., Mu, X. and Du, G. (2016) Microtubule-stabilizing agents: new drugs discovery and cancer therapy. Pharmacol. Ther. 162, 134-143. 


\section{MATERIALS AND METHODS}

Molecules| Working concentrations of $100 \mathrm{nM}$ nocodazole and $100 \mathrm{nM}$ taxol were prepared from stocks diluted in DMSO. Cells were incubated with nocodazole and taxol for $3 \mathrm{~h}$. Paclitaxel (Selleck Chemicals) was dissolved in DMSO. The placebo control consisted of the same volume of DMSO. Paclitaxel was administered at a dose of $10 \mathrm{mg} / \mathrm{kg} /$ day by intraperitoneal injection using a $27 \mathrm{G} 5 / 8$ syringe when mice were 4 months of age and continuing until 5 months of age.

Mice| $L m n a^{\mathrm{H} 222 \mathrm{P} / \mathrm{H} 222 \mathrm{P}}$ mice (31) were fed chow and housed in a disease-free barrier facility at $12 \mathrm{~h} / 12 \mathrm{~h}$ light/dark cycles. All animal experiments were approved by the French Ministry of Health at the Center for Research in Myology for the Care and Use of Experimental Animals. The animal experiments were performed according to the guidelines from Directive 2010/63/EU of the European Parliament on the protection of animals used for scientific purposes.

Dye transfer assay 3 month-old $L m n a^{\mathrm{H} 222 \mathrm{P} / \mathrm{H} 222 \mathrm{P}}$ mice were sacrificed by cervical dislocation under deep ether anaesthesia. Heart were quickly removed and transferred to ice-cold oxygenated standard salt solution containing $125 \mathrm{mM} \mathrm{NaCl}, 4 \mathrm{mM} \mathrm{KCl}, 10 \mathrm{mM}$ glucose, $1.25 \mathrm{mM} \mathrm{NaH}{ }_{2} \mathrm{PO}_{4}, 25 \mathrm{mM}$ $\mathrm{NaHCO}_{3}, 2 \mathrm{mM} \mathrm{CaCl}$ and $1 \mathrm{mM} \mathrm{MgCl}$. Cardiac ventricles were cut longitudinally, followed by embedding in $2.5 \%$ low melting temperature agarose (Biozym Scientific) at $30^{\circ} \mathrm{C}$, then sliced at 250 $\mu \mathrm{m}$ using a vibrating microtome (Leica). Dye-coupling experiments were performed as previously described (35). Individual cardiomyocytes were injected with the dye by iontophoretically injection. Intracellular communication was monitored under fluorescence microscope (Zeiss) and the dye spread area was quantified (Fiji software). The analysis was blinded to the genotype of the cells.

Isolation of mouse cardiomyocytes| Wild type and $L m n a^{\mathrm{H} 222 \mathrm{P} / \mathrm{H} 222 \mathrm{P}}$ mice were anesthetized with 
pentofurane. Ventricular cardiomyocytes were isolated as described in the Alliance for Cellular Signaling protocol PP00000125 (http://www.signaling-gateway.org/data/ProtocolLinks.html). Briefly, hearts were removed and the aorta cannulated. After $\mathrm{Ca}^{2+}$-free buffer was perfused for two minutes, $0.25 \mathrm{mg} / \mathrm{ml}$ collagenase I/II (Roche) solution was perfused through the coronary arteries for $6 \mathrm{~min}$ with $12.5 \mathrm{mM} \mathrm{Ca}^{2+}$. Left ventricular tissue was teased apart and pipetted to release individual cells. After enzymatic dispersion, $\mathrm{Ca}^{2+}$ concentration in the buffer containing bovine serum albumin was elevated in three steps up to $500 \mathrm{mM}$.

Protein extraction and immunoblotting| Total proteins were prepared by resuspending mouse heart (Cell Signaling) with the addition of protease inhibitors $(25 \mathrm{mg} / \mathrm{ml}$ aprotinin, $10 \mathrm{mg} / \mathrm{ml}$ leupeptin, 1 $\mathrm{mM}$ 4-[2-aminoethyl]- benzene sulfonylfluoride hydrochloride and $2 \mathrm{mM} \mathrm{Na}_{3} \mathrm{VO}_{4}$ ). The lysates were sonicated ( 3 pulses of $10 \mathrm{~s}$ at $30 \%$ amplitude) to allow dissociation of protein from chromatin and solubilization. Sample protein content was determined by the BiCinchoninic Acid Assay protein assay (Thermo Fisher Scientific). Extracts were analyzed by SDS-PAGE using a 10\% gel and transferred onto nitrocellulose membranes (Invitrogen). Subsequent to being washed with Tris-buffered saline containing $1 \%$ Tween 20 (TBS-T), the membranes were blocked in 5\% bovine serum albumin (BSA) in TBS-T for $1 \mathrm{~h}$ at room temperature, then incubated with the appropriate antibody overnight at $4^{\circ} \mathrm{C}$. Subsequent to being washed with TBS-T, the membranes were incubated with horseradish peroxidaseconjugated anti-rabbit or anti-mouse antibodies for $1 \mathrm{~h}$ at room temperature. After washing with TBS$\mathrm{T}$, the signal was revealed using Immobilon Western Chemiluminescent HorseRadish Peroxidase (HRP) Substrate (Millipore) on a G-Box system with GeneSnap software (Ozyme).

Antibodies| Primary antibodies used were: anti-Cx43 (Cell Signaling), anti- $\alpha$-tubulin (Abcam), antiacetylated $\alpha$-tubulin (Santa Cruz Biotechnology). Secondary antibodies for immunofluorescence were Alexa Fluor-488 conjugated goat anti-rabbit IgG, Alexa Fluor 568-conjugated goat anti-mouse IgG and Alexa-Fluor-488-conjugated donkey anti-goat IgG (Life Technologies). Secondary antibodies for 
immunoblotting were HRP-conjugated rabbit anti-mouse and goat-anti rabbit IgG (Jackson ImmunoResearch).

Immunofluorescence microscopy| For immunofluorescence microscopy, frozen tissues were cut in 8 $\mu$ m-thick sections. Cryosections were fixed (15 min, $4 \%$ paraformaldehyde in phosphate-buffered saline [PBS] at room temperature), permeabilized (10 min, 0.5\% Triton X-100 in PBS) and blocked (1 h, PBS with $0.3 \%$ Triton X-100, 5\% BSA). Sections were incubated with primary antibodies (overnight, $4^{\circ} \mathrm{C}$, in PBS with $0.1 \%$ Triton $\mathrm{X}-100$ and $1 \%$ BSA) and washed in PBS. The sections were then incubated for $1 \mathrm{~h}$ with secondary antibodies. Sections were washed with PBS and slides were mounted in Vectashield mounting medium with dapi (Vector Laboratories). Cardiomyocytes were washed with PBS and fixed with 4\% paraformaldehyde in PBS for 10 min. Cells were permeabilized with $0.2 \%$ Triton X-100 diluted in PBS for 7 min and non-specific signals were blocked with $0.2 \%$ Triton X-100, 5\% BSA for $30 \mathrm{~min}$. The samples were then incubated with primary antibody for $1 \mathrm{~h}$ in PBS with $0.1 \%$ Triton X-100 and $1 \%$ BSA at room temperature. Cells were washed with PBS and incubated for $1 \mathrm{~h}$ with secondary antibodies. F-actin was stained with Alexa Fluor 568-phalloidin and G-actin with Alexa Fluor 488-deoxyribonuclease I for $1 \mathrm{~h}$ at room temperature. Cells and slides were then mounted in Vectashield mounting medium with dapi (Vector Laboratories). Immunofluorescence microscopy was performed using an Axiophot microscope (Carl Zeiss). All the images were digitally deconvolved using Autodeblur v9.1 (Autoquant) deconvolution software and were processed using Adobe Photoshop 6.0 (Adobe Systems).

Electron microscopy| Freshly harvested left ventricle apex was cut into small pieces and immediately fixed by immersion in $2.5 \%$ glutaraldehyde diluted in PBS for $1 \mathrm{~h}$ at room temperature. After washing in PBS, samples were post-fixed with $1 \% \mathrm{OsO}_{4}$, dehydrated in a graded series of acetone and embedded in an epoxy resin. Ultrathin sections were cut at 90nm and stained with uranyl 
acetate and lead citrate, examined using a transmission electron microscope (JEOL 1011) and photographed with a digital Erlangshen 1000 camera (GATAN), using Digital Micrograph software.

Electrocardiography $\mid$ Electrocardiograms were recorded from mice using the non-invasive ecgTUNNEL (Emka Technologies) with minimal filtering. Waveforms were recorded using Iox Software and intervals were measured manually with ECG Auto. The electrocardiographer was blinded to mouse genotype.

Statistics| Statistical analyses were performed using GraphPad Prism software. Statistical significance between groups of mice analyzed by electrocardiography was analyzed with a corrected parametric test (Welch's $t$ test), with a value of $P<0.05$ being considered significant. To validate results of echocardiographic analyses, we performed a non-parametric test (Wilcoxon-Mann-Whitney test). For all other experiments, a two-tailed Student's $t$ test was used with a value of $P<0.05$ considered significant. Values are represented as means \pm standard errors of mean (SEM). Sample sizes are indicated in the figure and table legends. 
TABLES

2 tables 


\begin{tabular}{|c|cc|cc|cc|}
\hline Genotype & wild type & Lmna $^{\mathrm{H} 22 \mathrm{P} / \mathrm{H} 222 \mathrm{P}}$ & wild type & Lmna $^{\mathrm{H} 222 \mathrm{P} / \mathrm{H} 22 \mathrm{P}}$ & wild type & Lmna $^{\mathrm{H} 22 \mathrm{P} / \mathrm{H} 222 \mathrm{P}}$ \\
$\mathbf{n}$ & 16 & 17 & 7 & 20 & 9 & 20 \\
Age, months & 3 & 3 & 4 & 4 & 5 & 5 \\
\hline RR, ms & $90.1 \pm 3.6$ & $90.1 \pm 7.3$ & $87.9 \pm 2.2$ & $88.9 \pm 7.5$ & $88.6 \pm 6.1$ & $115.7 \pm 27.3^{* * *}$ \\
PR, ms & $31.4 \pm 2.3$ & $33.7 \pm 2.7$ & $32.7 \pm 1.1$ & $34.4 \pm 2.1^{*}$ & $32.3 \pm 1.7$ & $41.6 \pm 5.1^{* * *}$ \\
QRS, ms & $16.1 \pm 2.2$ & $15.6 \pm 1.2$ & $15.1 \pm 0.7$ & $16.1 \pm 1.4^{*}$ & $15.1 \pm 1.7$ & $18.6 \pm 2.5^{* * *}$ \\
\hline
\end{tabular}

Table 1| Electrocardiographic parameters for male $L m n a^{\mathrm{H} 222 \mathrm{P} / \mathrm{H} 222 \mathrm{P}}$ mice at 3, 4 and 5 months of age.

Values are means \pm standard errors of means.

$* P \leq 0.05$ and $* * * P \leq 0.0005$ between wild type and $L m n a^{\mathrm{H} 222 \mathrm{P} / \mathrm{H} 222 \mathrm{P}}$ mice.

\begin{tabular}{|c|c|c|c|c|}
\hline $\begin{array}{l}\text { Genotype } \\
\text { Treatment }\end{array}$ & $\operatorname{Lmna}^{\mathrm{H} 222 \mathrm{P} / \mathrm{H} 2221}$ & Lmna $^{\mathrm{H} 222 \mathrm{P} / \mathrm{H} 22 \mathrm{P}}$ & Lmna $^{\mathrm{H} 222 \mathrm{P} / \mathrm{H} 2 .}$ & $\operatorname{Lmna}^{\mathrm{H} 222 \mathrm{P} / \mathrm{H} 22 \mathrm{P}}$ \\
\hline $\mathbf{n}$ & 8 & 7 & 9 & 4 \\
\hline Age, months & 4 & 5 & 4 & 5 \\
\hline RR, ms & $94.24 \pm 2.2$ & $90.8 \pm 1.7$ & $91.3 \pm 1.4$ & $97.1 \pm 4.9$ \\
\hline PR, ms & $34.4 \pm 0.6$ & $41.9 \pm 1.2 * * *$ & $34.3 \pm 1.1$ & $36.9 \pm 1.1$ \\
\hline QRS, ms & $15.3 \pm 0.7$ & $22.6 \pm 0.7 * * *$ & $16.1 \pm 0.5$ & $17.9 \pm 0.2 \#$ \\
\hline
\end{tabular}

Table 2| Electrocardiographic parameters for $L m n a^{\mathrm{H} 222 \mathrm{P} / \mathrm{H} 222 \mathrm{P}}$ mice at 4 and 5 months of age treated or not with Paclitaxel.

Values are means \pm standard errors of means.

$* * * P \leq 0.0005$ between 4-month old and 5 month-old DMSO-treated $L m n a^{\mathrm{H} 222 \mathrm{P} / \mathrm{H} 222 \mathrm{P}}$ mice.

$\# P \leq 0.05$ between 4-month old and 5 month-old Paclitaxel-treated $L m n a^{\mathrm{H} 222 \mathrm{P} / \mathrm{H} 222 \mathrm{P}}$ mice. 
FIGURES

5 figures 
Figure 1
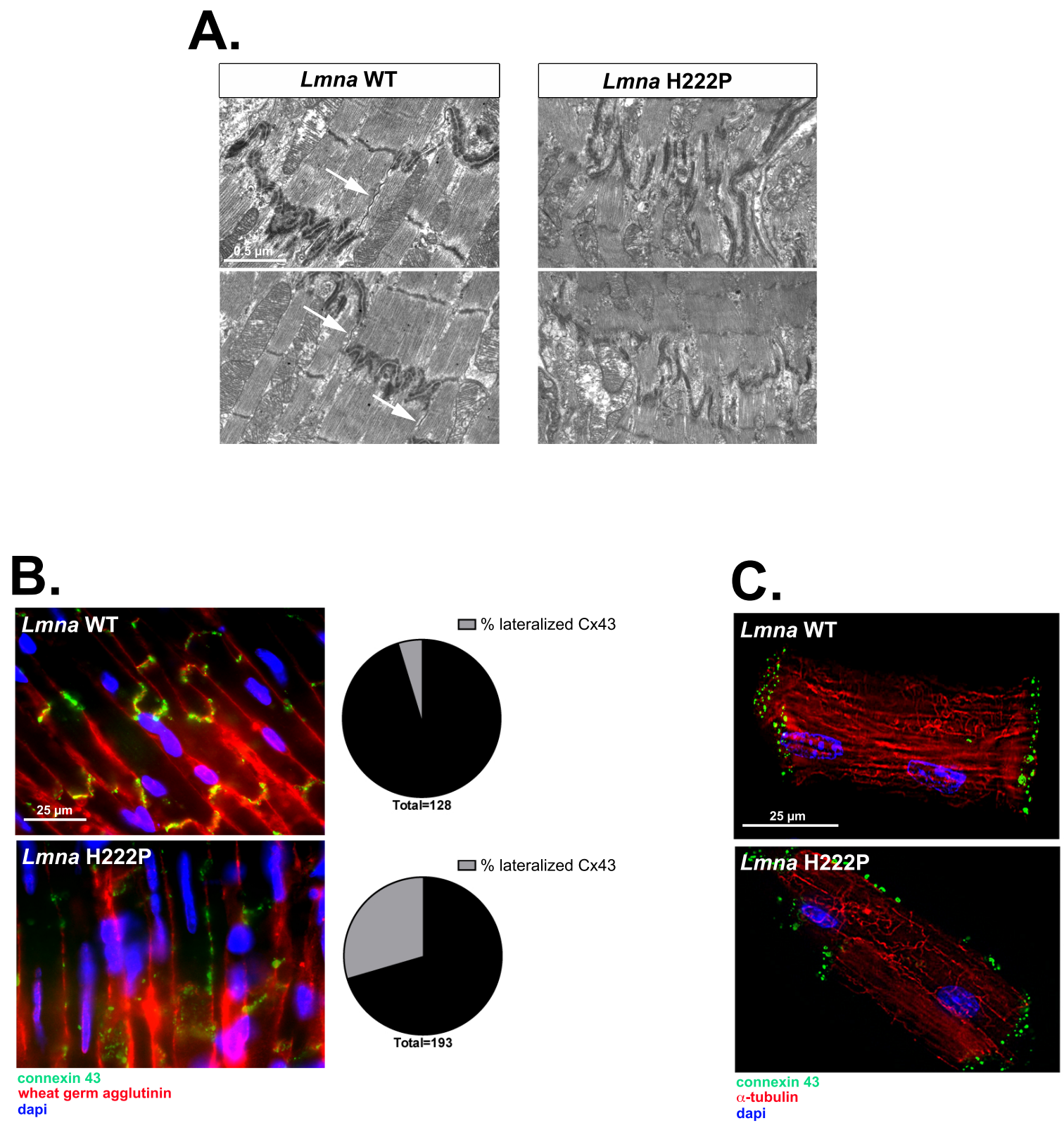

Figure 1| Remodelling of Cx43 in $L M N A$ cardiomyopathy. (A) Electron micrographs showing loss of gap junctions in hearts from 5 month-old male $L m n a^{\mathrm{H} 222 \mathrm{P} / \mathrm{H} 222 \mathrm{P}}(\mathrm{H} 222 \mathrm{P})$ mice compared to $L m n a^{+/+}$ (WT) mice. Arrow indicates gap junction. (B) Fluorescence micrographs showing Cx43 and wheat 
germ agglutinin labeling of cross-sections of hearts from 3 month-old male $\mathrm{Lmna}^{+/+}$(WT) mice and $L m n a^{\mathrm{H} 222 \mathrm{P} / \mathrm{H} 222 \mathrm{P}}(\mathrm{H} 222 \mathrm{P})$ mice. Arrows indicate lateralization of $\mathrm{Cx} 43$. Nuclei counter-stained with dapi are also shown. Data in pie graphs represent the quantification of lateralized $\mathrm{Cx} 43$ staining from $\mathrm{n}$ $=3$ independent experiments. (C) Fluorescence micrographs showing $\mathrm{Cx} 43$ and a-tubulin labeling of isolated cardiomyocytes of hearts from 3 month-old male $L_{m n a^{+/+}}(\mathrm{WT})$ mice and $L m n a^{\mathrm{H} 222 \mathrm{P} / \mathrm{H} 222 \mathrm{P}}$ (H222P) mice. Arrows indicate lateralization of Cx43. Nuclei counter-stained with dapi are also shown. 

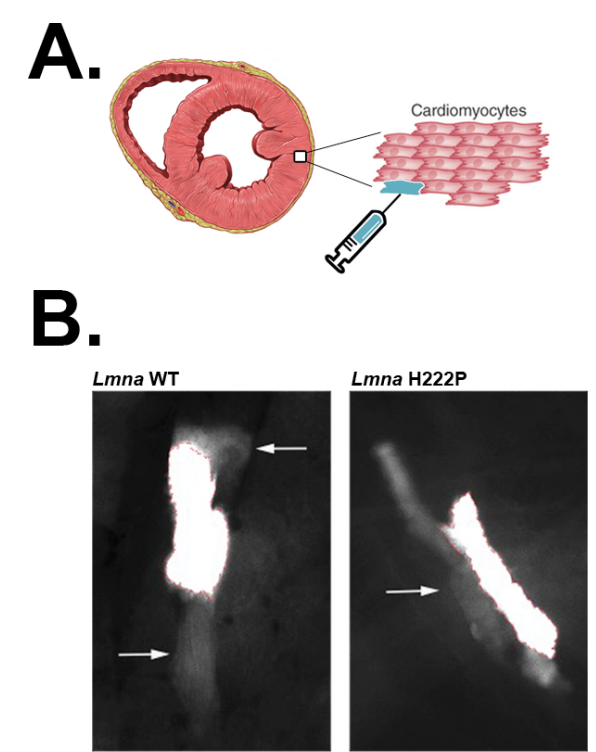

longitudinal spreading

lateral spreading
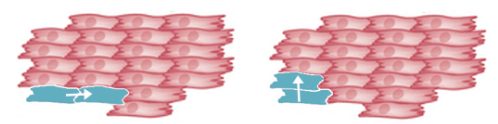

C.

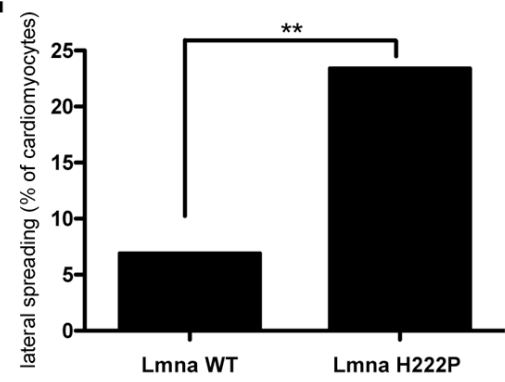

Figure 2| Alteration of communication between cardiac cells in $L M N A$ cardiomyopathy. (A)

Schematic representation of the ex-vivo cardiac dye transfer protocol. (B) Representative cells from Lmna $^{+/+}(\mathrm{WT})$ mice and Lmna ${ }^{\mathrm{H} 222 \mathrm{P} / \mathrm{H} 222 \mathrm{P}}(\mathrm{H} 222 \mathrm{P})$ mice cardiac slices after injection of carbofluorescein dye. The increased lateral spreading is most prominent in $L m n a^{\mathrm{H} 222 \mathrm{P} / \mathrm{H} 222 \mathrm{P}}(\mathrm{H} 222 \mathrm{P})$ mice cardiac slices 
cardiac slices. (C) Quantification of lateral spreading from $n=3$ independent experiments. Data in bar graph are represented as means $\pm \mathrm{SEM}\left({ }^{*} P<0.05\right)$. 

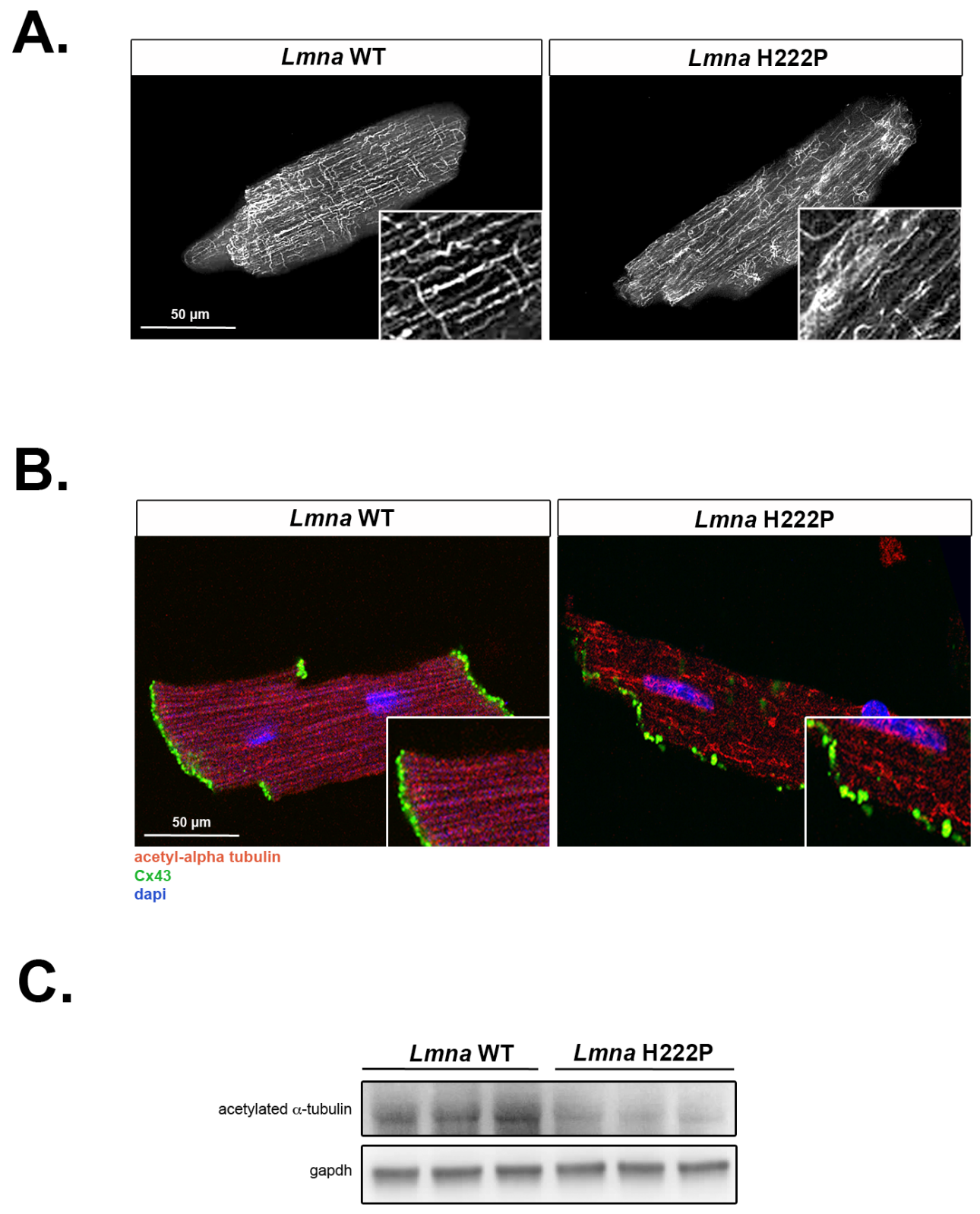

Figure 3| Changes in the microtubule cytoskeleton in cardiac cells from $\operatorname{Lmna}^{\mathrm{H222 \textrm {P } / \mathrm { H } 2 2 2 \mathrm { P }}}$ mice. (A) Fluorescence micrographs showing $\alpha$-tubulin labeling of isolated cardiomyocytes of hearts from male Lmna $^{+/+}$(WT) mice and Lmna ${ }^{\mathrm{H} 222 \mathrm{P} / \mathrm{H} 222 \mathrm{P}}(\mathrm{H} 222 \mathrm{P})$ mice. (B) Fluorescence micrographs showing $\mathrm{Cx} 43$ 
and acetylated $\alpha$-tubulin labeling of isolated cardiomyocytes of hearts from male $\mathrm{Lmna}^{+/+}$(WT) mice and $L m n a^{\mathrm{H} 222 \mathrm{P} / \mathrm{H} 222 \mathrm{P}}(\mathrm{H} 222 \mathrm{P})$ mice. Nuclei counter-stained with dapi are also shown. (C) Immunoblot showing acetylated $\alpha$-tubulin expression from isolated cardiomyocytes of hearts from male $\mathrm{Lmna}^{+/+}$ (WT) mice and $L m n a^{\mathrm{H} 222 \mathrm{P} / \mathrm{H} 222 \mathrm{P}}(\mathrm{H} 222 \mathrm{P})$ mice. Gapdh was used as a loading control. 

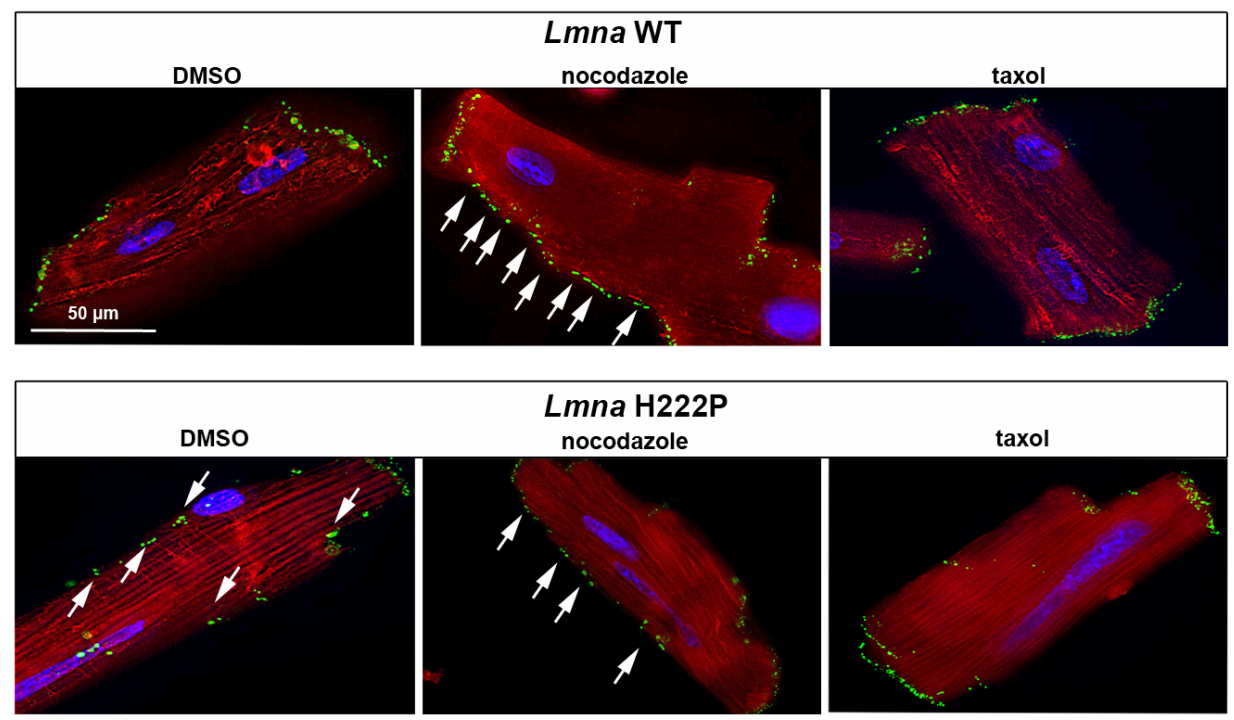

connexin 43

dapi

Figure 4| Connexin 43 localization at cell-cell junction is depending of microtubule organization in $\boldsymbol{L M N A}$ cardiomyopathy. Representative immuofluorescence micrographs of $\mathrm{Cx} 43$ and $\alpha$-tubulin staining of isolated cardiomyocytes treated or not with nocodazole or taxol of hearts from 3 month-old 
male $\mathrm{Lmna}^{+/+}$(WT) mice and isolated cardiomyocytes treated or not with nocodazole or taxol of hearts from 3 month-old male $\mathrm{Lmna}^{\mathrm{H} 222 \mathrm{P} / \mathrm{H} 222 \mathrm{P}}(\mathrm{H} 222 \mathrm{P})$ mice. Arrows indicate lateralization of $\mathrm{Cx} 43$. Nuclei counter-stained with dapi are also shown. 


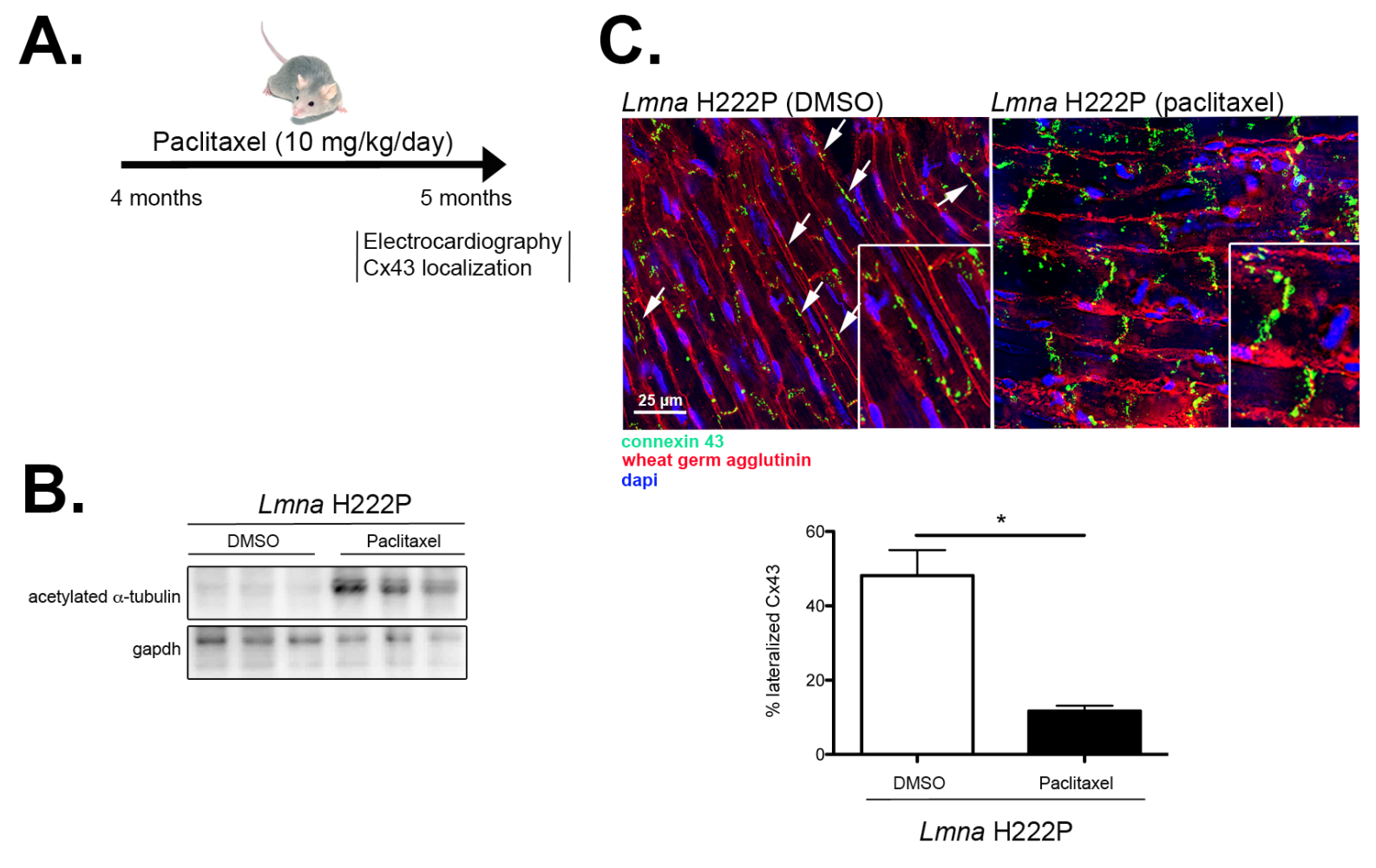

D.

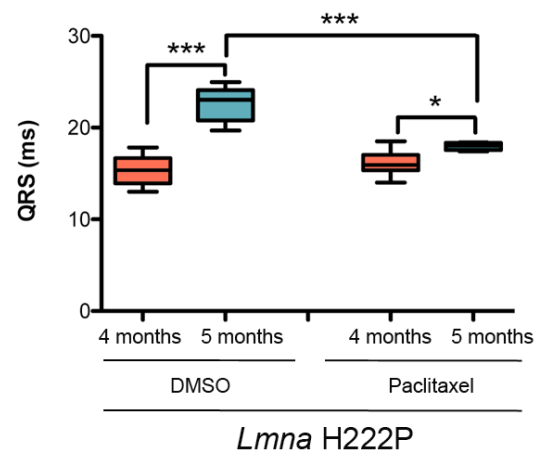

Figure 5| Paclitaxel improves cardiac electrical defects in $L M N A$ cardiomyopathy. (A) Schematic representation of the treatment protocol of $L m n a^{\mathrm{H} 222 \mathrm{P} / \mathrm{H} 222 \mathrm{P}}(\mathrm{H} 222 \mathrm{P})$ mice with Paclitaxel. (B) Immunoblot showing acetylated $\alpha$-tubulin expression from 5 month-old $L m n a^{\mathrm{H} 222 \mathrm{P} / \mathrm{H} 222 \mathrm{P}}(\mathrm{H} 222 \mathrm{P})$ mice treated with Paclitaxel. Gapdh was used as a loading control. (C) Representative immuofluorescence 
micrographs of $\mathrm{Cx} 43$ and wheat germ agglutinin staining of $L m n a^{\mathrm{H} 222 \mathrm{P} / \mathrm{H} 222 \mathrm{P}}(\mathrm{H} 222 \mathrm{P})$ mice after Paclitaxel treatment. Arrows indicate lateralization of $\mathrm{Cx} 43$. Nuclei counter-stained with dapi are also shown. Graph showing percentage of lateralization of $\mathrm{Cx} 43$ from 5 month-old $L m n a^{\mathrm{H} 222 \mathrm{P} / \mathrm{H} 222 \mathrm{P}}(\mathrm{H} 222 \mathrm{P})$ mice treated or not with Paclitaxel. Data are represented as means \pm SEM ( $n=150$ cardiomyocytes from 3 mice per group; ${ }^{*} P<0.05$ ). (D) Graphs showing mean QRS intervals in 5 month-old Lmna $a^{\mathrm{H} 222 \mathrm{P} / \mathrm{H} 222 \mathrm{P}}(\mathrm{H} 222 \mathrm{P})$ mice treated with Paclitaxel or DMSO. Data are represented as means \pm standard errors of means. Values are shown as 25 th to 75 th percentiles of data values. The line in the middle is the median. Whiskers (Tukey method) extend down to the minimum value and up to the maximum value. $* P<0.05, * * * P<0.0005$. 